\title{
Design of Entrepreneurship Learning Model with Practice Approach to Build Students' Entrepreneurship Values
}

\author{
Anik Kusmintarti*, Sidik Ismanu, Nur Indah Riwajanti \\ Accounting Department \\ State Polytechnic Malang \\ Malang, Indonesia \\ *Anik.kusmintarti@polinema.ac.id, \\ Sidik.ismanu@polinema.ac.id, nurindah12@gmail.com
}

\author{
Moh. Abdullah Anshori \\ Electro Department \\ State Polytechnic Malang \\ Malang, Indonesia \\ Anshori_ma@polinema.ac.id
}

\begin{abstract}
The purpose of this study is to design a learning model with practice approach to increase the level of students' entrepreneurial characteristics. The research sample included students interested in entrepreneurship, from the departments of Accounting, Electrical Engineering and Business Administration from the State Polytechnic of Malang. An application to measure students' entrepreneurial characteristics was used, and the data were analyzed using the independent $t$ test. Results of the study show that the entrepreneurial characteristics of students who attended entrepreneurship learning model with a practice approach, tended to be higher than when compared to before attending the course. Entrepreneurship learning consists of production training, calculating cost of production, determining the selling price, packaging, and marketing.
\end{abstract}

Keywords: entrepreneurial characteristics, entrepreneurship learning model, practice approach, application of measuring entrepreneurial characteristics

\section{INTRODUCTION}

In general, most countries in the world agree that entrepreneurship development will be a determinant of people's welfare. This means that the more the number of entrepreneurs in a country, the more prosperous is the country. McClelland [1] states that entrepreneurship is a key to economic development. Then, he also pointed out that when a country has many entrepreneurs then its economy has the potential to progress quickly and become a prosperous country.

Indonesian government is committed to increasing the number of entrepreneurs to create a prosperous society. In 2009 the Director General of Higher Education of Indonesia developed a program called 'Student Entrepreneurial Program'. The program is a part of the education strategy in universities, intended to facilitate students who have an interest in entrepreneurship and want to start a business on the basis of science, technology and art [2]. In 2017 the program was revitalized into the Indonesian Student Business Competition Program. Therefore, universities are expected to educate students in such a way that they internalize entrepreneurship. This is done by using effective educational strategies, such that the students have an entrepreneurial spirit that can develop their creativity to the highest. Then they can face present and future challenges, obstacles and problems in their lives. As such, upon graduation, the entrepreneurial intention of the students can be implemented and this will open more job opportunities for them. Hopefully, this will reduce unemployment. Further, such entrepreneurial education and experience can give rise to future entrepreneurs.

Entrepreneurs have a special characteristic that distinguishes them from the general public. The proposed Act of Indonesian Republic No. 21 concerning national entrepreneurship states that The National Entrepreneurship Movement functions as a forum fostering entrepreneurship mentality and increase the number of entrepreneurs in Indonesia through: lectures, entrepreneurship training; entrepreneurship development; cultivation of entrepreneurship, and highlight the role of family and community. Entrepreneurial education and entrepreneurship training is intended to build entrepreneurial characteristics, such as, discipline, courage, perseverance, hard work, creativity, innovative spirit, trustworthiness, become independent and responsible.

Entrepreneurial characteristics are personal characteristics inherent to individuals. These entrepreneurial characteristics play an important role in choosing an entrepreneurial career [3, 4]. Researchers examined entrepreneurial characteristics such as internal locus of control, need for achievement, propensity to risks, creativity, social networking and tolerance for ambiguity. The results of the study stated that the level of entrepreneurial characteristics of students increased after entrepreneurial education.

Internal locus of control is the extent to which an individual feels the events in his life which are in his own control [5]. Then, Rasheed [6] suggests that individuals with an internal locus of control believe that their personal actions directly affect the outcome of an event. Other researchers, Yusof [7] stated that people with an internal locus of control believe that they can control their life events. Then, Konia [8] explained that individuals with internal locus of control felt that the outcome of the event depended on their own behavior or permanent characteristics that they had. This study defines internal locus of control as the extent to which the individual 
[11]. Entrepreneurs tend to have a tolerance for high ambiguity level [5], and entrepreneurs are significantly more tolerant than managers [16]. The results of research Yusof [7] states that tolerance for ambiguity correlates with entrepreneurial tendencies. Thus, tolerance for ambiguity is an important trait for entrepreneurs because the challenges and potential for early business success cannot be predicted.

Entrepreneurial education is an important part, both in education and industry. Researchers define entrepreneurial education in various ways. Entrepreneurial education includes all activities that aim to foster entrepreneurial mindset, attitudes and skills, covering various aspects such as idea generation, start-ups, growth and innovation [17]. Other researchers, Linan [18] define entrepreneurial education as a teaching and learning activity about entrepreneurship, which includes the development of personal knowledge, skills, attitudes and character, in accordance with the age and development of students. This research tends to study the development of entrepreneurial attitudes and entrepreneurial characteristics of students.

Discussing entrepreneurial talent, some researchers stated that entrepreneurial talent is something inborn. Personal characteristics and entrepreneurial skills, on the other hand, can be developed through entrepreneurial education. This research refers to the opinion that entrepreneurship can be learned. Various entrepreneurial education programs include: entrepreneurship lectures, entrepreneurship seminars, entrepreneurial guest lectures, entrepreneurship trainings on topics related to personality development and the establishment of new businesses, internships in the industry, and entrepreneurship exhibitions.

Generally, the goal of entrepreneurial education is to increase students' awareness that entrepreneurship is a career choice, increasing the understanding of the process of establishing and managing new business ventures [19]. The achievement of the objectives of entrepreneurial education depends on the accuracy of the choice of methods used to deliver entrepreneurial education [20]. After the entrepreneurial education goals have been agreed upon, and specific limitations have been identified, then a teaching method is chosen [17]. If the purpose of entrepreneurial education is to increase understanding of entrepreneurship, then the most effective way is to provide information through the media, seminars and lectures. However, if the aim of entrepreneurial education is to equip students with entrepreneurial skills that can be applied directly, then the best way is to provide education and training that directly involves students in the entrepreneurial process such as training involving industry [21].

Learning-by-doing can be interpreted as a process full of emotion and motivation, where the level of motivation depends on: (1) what action is taken, (2) learning what happens and (3) what value is created [22]. In the concept of Learning-by-doing students work together with others, not only with classmates but also with external stakeholders. The interaction between students is based on a set of mediation artifacts that are used together, such as equipment, rules, processes, knowledge, signs, ideas, and so on.
Tolerance for ambiguity is a personality that influences the way a person manages information in ambiguous situations 
Pekrun [23] stated that student motivation and enjoyment increase through controlled and valued actions. Then, the participation of activities that are oriented towards challenges and valuable goals, can produce strong confidence, happiness and motivation [24].

Learning-by-doing approach fosters deep learning habits. It enhances the characteristics such as taking initiative, encouraging people to take initiatives and being responsible, taking actions that produce valuable results, benefitting the wider community; collaborating amongst mutual relations. If it produces something new and valuable to others, it is called creativity [25]. Information is obtained through listening and reading, while experience is gained through activities. Lackéus [26] stated that students must be involved in entrepreneurial activities, so that their entrepreneurial competence increases.

Higher education requires students to attend entrepreneurship courses and attend various entrepreneurship programs, including: attending entrepreneurship lectures and participating in the entrepreneurship programs such as entrepreneurship guest lectures, entrepreneurship seminars, entrepreneurship training, industry visits, and business practices. The effectiveness of entrepreneurial learning depends on the accuracy of the selected learning methods [6]. Therefore, the selection of learning methods must coordinate with the objectives of entrepreneurial learning.

Furthermore, to know the development of the level of entrepreneurial characteristics of students after attending entrepreneurial education requires measuring tools. Chen [15] developed CEAS (Chinese Entrepreneur Aptitude Scale), and stated that the average value of the entrepreneurial model group was significantly higher than the non-entrepreneurial model group. The researcher and his team developed the application of measuring entrepreneurial characteristics to evaluate the level of the student 'entrepreneurial characteristics after participating in various entrepreneurship programs. The entrepreneurial characteristics that measured consist of: internal locus of control, need for achievement, propensity to risks, creativity, social networking and tolerance for ambiguity.

Based on the description above, the purpose of this study is to design an Entrepreneurship Learning Model with a practical approach to building student's entrepreneurial characteristics.

\section{METHODS}

This research is an experimental research. The research sample included students majoring in accounting, business administration, and electronics who have intentions towards entrepreneurship. The sampling technique uses purposive sampling. The number of samples include 30 students. The stages of the research are: (1) Students are divided into 6 groups. (2) The study measures students' entrepreneurial characteristics, measuring their entrepreneurial characteristics in stage 1. (3) The results are then analyzed. (4) Entrepreneurial education is then provided based on practice, consisting of: training, internships, and business practices. (5) The entrepreneurial characteristics of students are measured in stage 2. (6) The results from testing the entrepreneurial characteristics of students in stage 1 and stage 2 are compared.
Data is analyzed using descriptive statistics and paired sample tests.

\section{RESULTS}

Entrepreneurial characteristics are measured after the subjects (30 students) go through entrepreneurial education using a practical approach, with training, to make bakery products in the teaching factory bakery. The training included calculating the cost of production, setting the selling price, marketing and making the cash flow reports. Figure 1 displays the entrepreneurship learning model with a practice approach.

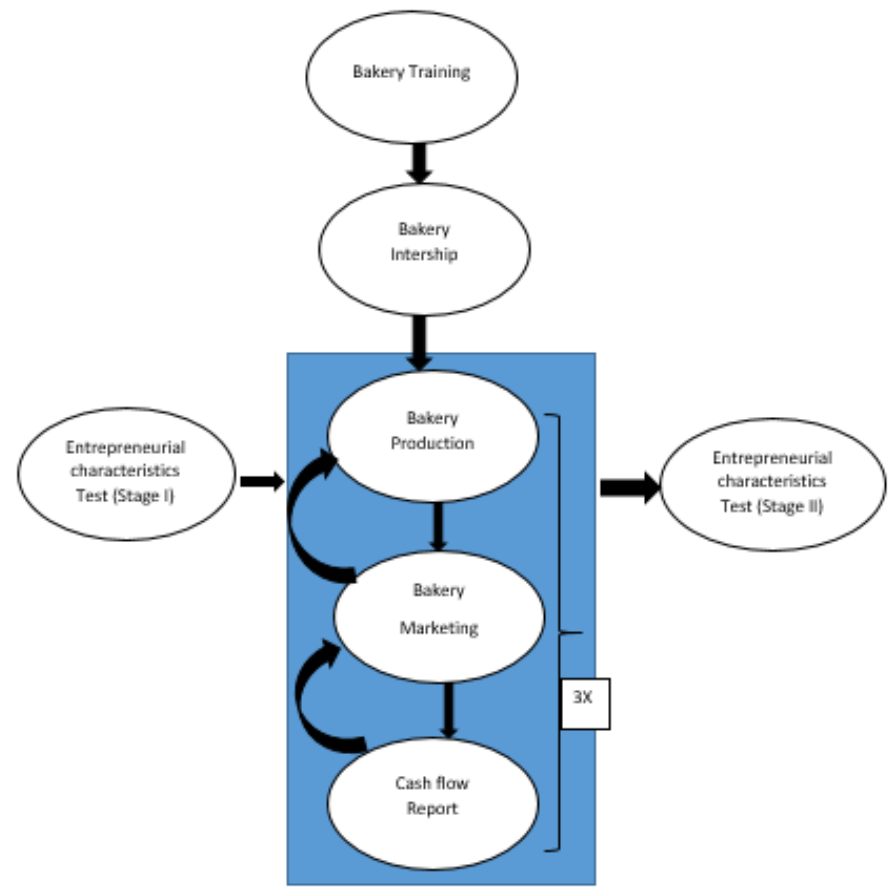

Fig. 1. The entrepreneurship learning model with practice approach.

Table 1 shows the average value of student's entrepreneurial characteristics before and after following the entrepreneurial education based on a practice approach. Descriptive analysis results showed that the average value of student's entrepreneurial characteristics after following the entrepreneurial education is higher than before the education.

TABLE I. THE AVERAGE VALUE OF THE STUDENT'S ENTREPRENEURIAL CHARACTERISTICS

\begin{tabular}{|c|c|c|c|}
\hline \multirow{2}{*}{$\begin{array}{c}\text { Entrepreneurial } \\
\text { Characteristics }\end{array}$} & \multicolumn{3}{|c|}{ Average Value } \\
\hline & $\begin{array}{c}\text { Before } \\
\text { Entrepreneurial } \\
\text { Education }\end{array}$ & $\begin{array}{c}\text { After } \\
\text { Entrepreneurial } \\
\text { Education }\end{array}$ & Difference \\
\hline $\begin{array}{l}\text { Internal Locus of } \\
\text { Control }\end{array}$ & 111.17 & 115.77 & 4,60 \\
\hline $\begin{array}{ll}\text { Need } & \text { for } \\
\text { achievement } & \end{array}$ & 76.90 & 80.27 & 3,67 \\
\hline $\begin{array}{ll}\text { Risk } & \text { taking } \\
\text { propensity } & \end{array}$ & 81.03 & 84.70 & 3,67 \\
\hline
\end{tabular}


values are created [22]. In learning by doing, students work together with others, not only with classmates but also with external stakeholders.

Learning by doing is learning using a practical approach, giving room to learners to learn while doing it. Through this approach, the students not only enjoy what they are doing but they can also increase enhance their entrepreneurial characteristics. These results are consistent with the opinions [25]. Learning-by-doing approach fosters deep learning habits; enhances the characteristics like initiativeness and responsibility because it encourages people to be proactive and produce results.

Therefore, the difference in the level of student's entrepreneurial characteristics before and after attending practice-based entrepreneurial education is analyzed with paired sample t test. Table 2 show the results of the average difference test.

TABLE II. THE AVERAGE DIFFERENCE TEST STUDENT'S ENTREPRENEURIAL CHARACTERISTICS BEFORE AND AFTER ENTREPRENEURIAL EDUCATION

\begin{tabular}{|l|l|l|l|l|}
\hline \multirow{2}{*}{$\begin{array}{c}\text { Entrepreneurial } \\
\text { characteristics }\end{array}$} & \multicolumn{2}{|c|}{ percentage } & \multirow{2}{*}{ Sig } \\
\cline { 2 - 3 } & \multicolumn{1}{|c|}{ Increase } & Decrease & & \\
\hline $\begin{array}{l}\text { Internal Locus of } \\
\text { Control }\end{array}$ & 70.0 & 30.0 & 3,925 & 0,000 \\
\hline Need for achievement & 63.3 & 36.7 & 2,755 & 0,010 \\
\hline $\begin{array}{l}\text { Risk taking } \\
\text { propensity for }\end{array}$ & 53.3 & 46.7 & 2,219 & 0,034 \\
\hline Social networking & 60.0 & 40.0 & 2,704 & 0,011 \\
\hline Creativity & 46.7 & 53.3 & 0,727 & 0,473 \\
\hline $\begin{array}{l}\text { Tolerance } \\
\text { ambiguity }\end{array}$ & 23.3 & 4,435 & 0,000 \\
\hline
\end{tabular}

Table 2 shows that the level of students' entrepreneurial characteristics increased, specifically, the difference before and after the education with creativity was not significant. This means that entrepreneurial education has been effective. The level of students' entrepreneurial characteristic after attending entrepreneurial education is higher than before. The results are consistent with Greenberg [9] which states that if the aim of entrepreneurial education is to equip students with entrepreneurial skills which can be implemented directly in the future, the appropriate learning method has to provide education and training that directly engages students in the entrepreneurial process. Explanations for entrepreneurial characteristics are examined as follows:

For the variable, internal locus of control, $70 \%$ of the sample have experienced an increase in the level of internal locus of control, whereas, it decreased by $30 \%$. The test results of the difference in the average value of the internal locus of control of 4.60 (Table 1) with $t$ of $3.925(p=0.000)$ is significant (Table 2). This means that there are significant differences in the level of internal locus of control before and after undergoing entrepreneurial education. 
For the variable tolerance for ambiguity, $76.7 \%$ of the The average value of student's internal locus of control after following entrepreneurial education is higher than the average value before the education. This means that entrepreneurship learning model with practice approach is able to improve the characteristic of internal locus of control.

For the variable, need for achievement, $63,3 \%$ of the sample have experienced an increase, whereas, $36.7 \%$ had a decrease. The test results showed a difference in the average value of the need for achievement (3.67, see Table 1) with $t$ of $2,775(p=0.010)$ is significant (Table 2). This means that there are significant differences in the need for achievement before and after undergoing entrepreneurial education.

The average value of the student's need for achievement after following entrepreneurial education is higher than the average value before the education. This means that the entrepreneurship learning model with practice approach is able to improve students' need for achievement.

For the variable, risk taking propensity, $53.3 \%$ of the sample have experienced an increase in the level of risk-taking propensity, meanwhile $46.7 \%$ decreased. The test results of the difference in the average value of risk-taking propensity (3.67, Table 1) with $\mathrm{t}$ of $2.219(\mathrm{p}=0.034)$ is significant (Table 2). This means that there are significant differences in the level of risk-taking propensity before and after following entrepreneurial education.

The average value of the students' risk-taking propensity after following entrepreneurial education is higher than the average value before the entrepreneurial education. This means that the entrepreneurship learning model with practice approach is able to improve the characteristic of risk-taking propensity.

For the variable, social networking, $60 \%$ of the sample have experienced an increase in the level of social networking, at the same time, $40 \%$ decreased. The test results of the difference in the average value of the social networking of 2.53 (Table 1) with t of $2.704(\mathrm{p}=0.011)$ is significant (Table 2). This means that there are significant differences in the level of social networking before and after following entrepreneurial education.

The average value of the students' risk-taking propensity after following entrepreneurial education is higher than the average value before following the education. This means that the entrepreneurship learning model with practice approach is able to improve the characteristic of social networking.

For the variable, creativity, $46.7 \%$ of the sample have experienced an increase in the level of creativity, meanwhile $53.3 \%$ decreased. The test results of the difference in the average value of the creativity of 0.97 (Table 1) with t of 0.727 $(p=0.473$ ) is not significant (Table 2 ). This means that there are no significant differences in the level of creativity before and after entrepreneurial education.

The average value of the students' creativity after entrepreneurial education is higher than the average value before the entrepreneurial education. This means that the entrepreneurship learning model with practice approach is able to improve their creativity but it is not significant. sample have experienced an increase in the level of tolerance for ambiguity, meanwhile $23.3 \%$ decreased. The test results of the difference in the average value of the tolerance for ambiguity of 3.67 (Table 1) with $t$ of $4.435(\mathrm{p}=0.000)$ is significant (Table 2). This means that there are significant differences in the level of the students' tolerance for ambiguity before and after following entrepreneurial education.

The average value of students' tolerance for ambiguity after following entrepreneurial education is higher than the average value from before the education. This means, the entrepreneurship learning model with practice approach is proven to improve the characteristic of tolerance for ambiguity

\section{ANALYSIS}

This study examines the entrepreneurial characteristics, consisting of internal locus of control, need for achievement, propensity to risk, creativity, social networking, and tolerance for ambiguity. The students are attending entrepreneurial education, namely, bakery making training, internship in bakery factory, practice of making bakery, calculation of production costs, determining the selling price, marketing, and making cash flow statements.

The results of the study show that the level of students' entrepreneurial characteristics after attending entrepreneurship education is higher than before. This means that the goal of entrepreneurial education to build students' entrepreneurial values is being achieved through learning from a practical approach. The findings of this study are consistent with the opinion [25], that learning methods that foster deep learning can enhance the characteristics of initiativeness and responsibility, because these learning methods encourage people to take initiatives that produce something useful. Furthermore, students who study business through hands-on practice can improve their entrepreneurial competencies [26].

These findings explain that the selection of the learning method is in accordance with the entrepreneurial education objectives [20], namely build Students' Entrepreneurial Values. Thus, entrepreneurship education has been carried out effectively.

\section{CONCLUSION}

Entrepreneurial learning model of directly involving students in the entrepreneurial process becomes a routine for students. Learners in this case study were happy to follow the learning process and the knowledge gained will always be remembered. In the long run, the level of student entrepreneurial characteristics increase. Learning activities include: training in bakery making, internship in bakery factory, practice of making bakery, calculating production costs, determining the selling price, marketing, and making cash flow statements. The difference in the average value of students' entrepreneurial characteristics before and after participating in learning is significant, except for the difference in the characteristic of creativity. It is not significant. 
[11] T.W. Zimmerer, N.M. Scarborough, and D. Wilson. Essentials of Entrepreneurship and Small Business Management, 5nd. 1997. D. A. Kwary and D. Fitriasari.

We are grateful to the director of Malang State Polytechnic for enabling us to use the teaching factory bakery for conducting our research. So, we were able to perform all activities related to our research like training, production, and internship able to perform. Thanks to all our respondents who voluntarily followed the entrepreneurship learning model with practice approach.

\section{REFERENCES}

[1] D.C. McClelland, The Achieving Society, Van Norstand, Princeton, NY. 1961.

[2] Directorate General of Higher Education, Ministry of National Education. Panduan Program Mahasiswa Wirausaha (PMW). Jakarta. 2010.

[3] S. Karimi, H. Biemans, T. Lans, Z. Arasti, M. Chizari, and M. Mulder. Application of structural equation modelling to assess the impact of entrepreneurial characteristics on students 'entrepreneurial intentions. $\mathrm{H}$. Fulford (Ed.): Proceedings of ECIE. The 6th European Conference on Entrepreneurship and Innovation, Robert Gordon University, Aberdeen, Scotland, UK. 2011, pp.954-967.

[4] A. Salamzadeh, M.A. Azimi and D. A. Kirby. Social entrepreneurship education in higher education: insights from a developing country. International Journal of Entrepreneurship and Small Business. 2013, Vol. 20, No. 1, pp.17-34.

[5] D.L. Sexton and N. Bowman. The Entrepreneur: A Capable Executive and more. Journal of Business Venturing. 1985, Vol.1 pp.129-140

[6] H.S. Rasheed. Developing Entrepreneurial Characteritics in Youth: The Effects of education and Enterprise Experience. International Journal of Entrepreneurship education. 2003.

[7] M. Yusof, M.S. Sandhu and K.K. Jain. Relationship Between psychological characteristics and entrepreneurial inclination: A Case Study of Student at University Tun Abdul Razak (UNITAR). Journal of Asia Entrepreneurship and Sustainability. 2007, Vol.111 No.2

[8] M. Kobia and D. Sikalieh. Towards a search for the meaning of entrepreneurship, Journal of European Industrial Training. 2010, Vol. 34 No. 2 pp.110-127

[9] J. Greenberg and R.A. Baron. Behavior in organization. Ninth edition. Pearson Education. New Jersey. 2008.

[10] I. Kuip and I. Verheul. Early development of entrepreneurial qualities: the role of initial education. SCALES-paper N200311. EIM Business \& Policy Research, Zoetermeer. 2003.
[12] L.A. Lefton. Psychology. Third Edition. Allyn and Bacon, Inc. Massachusetts. 1985.

[13] E. Sefertzi. Creativity. Innoregio Project. 2000.

[14] R.J. Taormina and S.K. Lao. Measuring Chinese entrepreneuria motivation: Personality and environmental influences. International journal of Entrepreneurial Behaviour \& Research. 2007, Vol.13 No.4 pp.200-221.

[15] W. Chen, C.S. Weng and H. Hsu. A Study of the entrepreneurship of Taiwanese youth by the Chinese Entrepreneur Aptitude Scale. Journal of Technology Management in China. 2010, Vol.5 No.1.pp.26-39.

[16] J. Schere. Tolerance of ambiguity as a discriminating variable between entrepreneurs and managers. Academy of Management Best Paper Proceedings. 1982, No.42 pp. 404-408.

[17] A. Fayolle and B. Gailly. From craft to science: Teaching models and learning Processes in Entrepreneurship Education. Journal of European Industrial Training. http://dx.doi.org/10.1108/03090590810899838. 2008, 32(7). pp.569-593.

[18] F. Linan, J.A. Moriano and A. Zarnowska. Teaching Psychology of Entrepreneurship. Perspective from Six European. Primera edición. Impreso en España. Printed in SpainCountries. 2008.

[19] Z. Arasti, M. K. Falavarjani, and N. Imanipour. A Study of Teaching Methods in Entrepreneurship Education for Graduates Students. Higher Education Studies. http://www.ccsenet.org/hes. 2012, Vol.2 No.1.

[20] P.F. Drucker. Innovation and Entrepreneurship. McGraw Hill. 1994.

[21] U. Hytti and C. O'Gorman. What is "enterprise education"? An analysis of the objectives and methods of enterprise education programmes in four European countries. Education + Training. 2004, Vol. 46 No. 1 pp.11-23

[22] OECD. Education policy Outlook. 2015.

[23] R. Pekrun. The control-value theory of achievement emotions Assumptions, corollaries, and implications for educational research and practice. Educational Psychology Reviews. doi: 10.1007/s10648-0069029- 9. 2006, 18(3). Pp.315-341.

[24] N. Cantor and C.A. Sanderson. Life task participation and well-being: The importance of taking part in daily life. In D. Kahnerman, E. Diener, and N. Schwarz (Eds.), Well-being: The foundation of hedonic psychology. New York: Russell Sage Foundation. 2003, pp.230-243.

[25] T. Amabile and M. Khaire. Creativity and the Role of the Leader. Harvard Business Review. 2008, pp.100-109.

[26] M. Lackéus and K.W. Middleton. Venture Creation Programs - Bridging Entrepreneurship Education and Technology Transfer. Education + Training, In review process. 2013. 